Research Article

\title{
Morphological, Physiological, and Biochemical Characterization of Drought-Tolerant Wheat (Triticum spp.) Varieties
}

\author{
Alemayehu Tefera ${ }^{(D},{ }^{1}$ Mulugeta Kebede ${ }^{(D},{ }^{1}$ Kassu Tadesse ${ }^{(D},{ }^{2}$ and Tsegaye Getahun ${ }^{3}$ \\ ${ }^{1}$ School of Applied Natural Science, Department of Applied Biology, University of Adama Science and Technology, P.O. Box 1888, \\ Adama, Ethiopia \\ ${ }^{2}$ Kulumsa Agricultural Research Centre, Ethiopian Institute of Agricultural Research, P.O. Box 489, Kulumsa, Ethiopia \\ ${ }^{3}$ Addis Ababa University, Institute of Biotechnology, Addis Ababa, Ethiopia
}

Correspondence should be addressed to Alemayehu Tefera; betsealex49@gmail.com

Received 19 September 2020; Revised 11 February 2021; Accepted 20 February 2021; Published 28 February 2021

Academic Editor: Vera Popovic

Copyright (c) 2021 Alemayehu Tefera et al. This is an open access article distributed under the Creative Commons Attribution License, which permits unrestricted use, distribution, and reproduction in any medium, provided the original work is properly cited.

\begin{abstract}
Wheat is one of the most important cereal crops and extensively cultivated in wide ranges of altitudes in Ethiopia. With an alarming population growth in the era of climatic change, there is a need for further crop improvement for sustainable production. In this regard, the study was carried out at the Kulumsa Agricultural Research Center (KARC) in a rainout shelter to investigate the responses of durum and bread wheat varieties to soil water stress in terms of selected morphological, physiological, and biochemical parameters. The 2 factors were combined factorially and arranged in a randomized complete block design with 3 replications. The 12 wheat varieties, 6 bread wheat and other 6 durum wheat, were sown in pots under well-watered (100\% field capacity) and water-stressed (30\% field capacity) conditions. Results revealed that water stress resulted in $26 \%, 9 \%, 23 \%, 16 \%$, and $11 \%$ reductions in plant height, spike length, number of spikelets spike ${ }^{-1}$, relative water, and chlorophyll contents, respectively. The tested wheat varieties under water stress produced $28 \%$ and $6 \%$ more proline content and total soluble sugar, respectively, as mitigation strategies against drought. Results further exhibited that wheat varieties significantly differed in all of the measured traits except for the plant height and relative water content. The present study verified that the biochemical parameters needs to be considered as better traits to select wheat (Triticum spp.) varieties for drought tolerance under water stress conditions.
\end{abstract}

\section{Introduction}

Wheat is one of the most important cereal crops widely grown in an extensive range of altitudes by smallholder farmers under rain-fed conditions in Ethiopia [1]. Most wheat-producing areas in Ethiopia lie between $6^{\circ}$ and $16^{\circ} \mathrm{N}$ latitude and $35^{\circ}$ and $42^{\circ} \mathrm{E}$ longitudes at an altitude range from 1500 to 3000 meters above the sea level (m.a.s.l). However, the most suitable agroecological zones fall in between 1900 and 2700 m.a.s.l [1]. Wheat has the major share in Ethiopian agriculture in terms of area coverage. It ranks fourth next to tef (Eragrostis tef (Zuccagni), Trotter), maize (Zea mays L.), and sorghum (Sorghum bicolor (L) Moench) in terms of area coverage [2]. Concerning production, wheat holds the fourth largest proportion (15.17\%) next to maize (27.43\%), teff (17.26\%), and sorghum $(16.89 \%)$ [2]. The total area under wheat coverage and its total production in the main season of 2018 was 1.7 million hectares and 4.6 million tones, respectively [2]. It is grown by an estimated 4.2 million farmers [2].

Drought is one of the most significant abiotic factors of dry land regions and leads to poverty, food insecurity, and malnutrition in sub-Saharan African countries including Ethiopia [3]. It can severely affect and reduce the yield and productivity of food crops worldwide up to $70 \%$ [4]. Studies showed that about $75 \%$ of the landmass of Ethiopia is classified under dry lands. These regions have short growing season per year, usually $45-120$ days and face soil moisture 
stress for majority of the days of the year [5]. In contrast to the increasing area coverage under dry land, the population of the country continues growing. Studies indicated that the population of Ethiopia increased from 83 million to 109 million between 2008 and 2018 [6]. During the same period, however, the production of cereals increased from 13.72 to 26.78 metric tons only $[1,7]$. This indicates that the productivity of crops needs to be increased at a higher rate in order to feed the ever-increasing population of the country.

The stresses induced by drought negatively affect plant growth and development, causing a sharp decline in crops productivity [8]. This, in turn, can have a substantial impact on the agriculture of the affected region or country and bring significant harm to the economy [9]. Water scarcity is one of the stresses in drought-prone regions. Owing to the water stress, the productivity of crops in dry lands is usually lower than the optimum environments [10].

Water stress induces significant alterations in plants functioning $[11,12]$. Plants responses to water stress are complex due to unpredictable factors in the environment and the interaction with other abiotic and biotic factors which involve changes in their morphology, physiology, and metabolism [4, 13]. The degree of adaptations to the environmental stresses induced by drought varies considerably among plants and species $[11,12]$. Some plants have a set of morphological, physiological, and biochemical adaptation strategies that allow them to cope up water stress conditions $[12,14]$. The response of plants to water stress is influenced by several factors such as the development stage, intensity, and duration of stress and cultivar genetics [15]. These plants have tolerance limit to withstand stresses. As the water stress becomes more severe, functional damage and loss to plant parts can be occurred [13].

Agriculture in Ethiopia is predominantly traditional, and thus, mainly landraces are grown $[1,16]$. This is mainly attributed to the test of very few available Ethiopian improved varieties to adverse farming conditions that prevail among the smallholder farmers such as drought in terms of their physiological and biochemical traits [17]. It is also ascribed to the unavailability of seeds of improved varieties to farmers in sufficient quantity $[18,19]$. The phenomena encountered to wheat crop and extended duration of water stress can lead to severe reduction in overall production [20].

The development of drought tolerant varieties has been the approach used to alleviate the negative effects of water stress on crops and crop yields [21]. To date, the conventional plant breeding techniques have allowed the development of drought-tolerant and high-yielding crop varieties [17]. However, the shortcomings of this approach are that it is time consuming, labor intensive, and may lead to the loss of other desirable traits from the hosts' gene pool [22].

The other approach to cope up with the adverse effect of environmental stresses is screening of the available wheat varieties to water scarcity $[23,24]$. The adaptive responses to water deficit include morphological, physiological, and biochemical changes such as changes in growth rate, stomatal conductance, tissue osmotic potential, and antioxidant defenses [25-27]. Drought stress induces biosynthesis and significantly increases proline and total soluble sugar contents in comparison to plants under optimum production condition [28]. According to Manuchehri et al. [29], the amount of soluble sugars, proline concentration, and activity of free radical scavenging enzymes increased significantly under stress conditions to combat the accumulation of the reactive oxygen species. The varieties with enhanced capacity to syntheses such biochemicals in response to the water stress have relatively superior potential to offer higher yield and contributed to ensuring food security in the dry lands [14]. Therefore, the objective of this research was to study the effect of soil water stress on selected morphological, physiological, and biochemical parameters of durum wheat (Triticum durum Desf.) and bread wheat (Triticum aestivum L.) varieties and to determine the traits, which can be used for identification of tolerant wheat varieties under water stress conditions.

\section{Materials and Methods}

The pot experiment was carried out at Kulumsa Agricultural Research Center (KARC) from March to July 2019 under rainout shelter. The site is located at $8^{\circ} 08^{\prime} \mathrm{N}$ and $39^{\circ} 08^{\prime} \mathrm{E}$ at an elevation of $2200 \mathrm{~m}$ a.s.l. in Arsi administrative zone of Oromia Regional State, $167 \mathrm{~km}$ southeast of the capital city, Addis Ababa. The agroecology of the study area is characterized as cool highland to semiarid climate. The area has a unimodal kind of annual rainfall, which extends from March to September; however, the peak season is from July to August. The data obtained from the weather station located at the KARC revealed that the area receives a mean annual precipitation of $809 \mathrm{~mm}$, whereas the mean maximum and minimum temperatures are $23.08^{\circ} \mathrm{C}$ and $9.9^{\circ} \mathrm{C}$, respectively. The dominant soil type of the study area is Vertic Luvisol [30].

2.1. Experimental Design and Treatments. The pot experiment was designed to characterize drought-resistant bread and durum wheat varieties morphologically, physiologically, and biochemically. The seeds were sown, and the plants were grown in a rainout shelter, which is similar to the natural conditions with respect to natural daylight duration and air temperature of the period. The experiment had two factors, wheat varieties and water management. The total number of varieties tested was 12, while the treatments for water management were well-watered and stressed conditions. The treatments were combined factorially, which made up a total of 24 treatments, and were arranged in randomized complete block design with 3 replications. The 6 different bread wheat (Triticum aestivum L.) varieties, namely, Wane, Deka, Kakaba, Ogolcho, Pavon-76, and Kingbird and 6 durum wheat (Triticum durum Desf.) varieties, namely, Donmatio, Mangudo, Utuba, Alemtena, Ude, and Mukuye were used. The brief description of each of the 12 wheat varieties is summarized in Table 1. All those varieties were released to mid to lowlands. The major criteria considered for the selection of those varieties were their potential resistance to water stress. The bread and durum wheat varieties were collected from KARC and Debrezeit Agricultural Research Center (DARC), respectively. 
TABLE 1: Profile of bread and durum wheat varieties tested in this study.

\begin{tabular}{|c|c|c|c|c|}
\hline Variety name & Origin & $\begin{array}{c}\text { Breeder } \\
\text { (maintainer) }\end{array}$ & $\begin{array}{l}\text { Year of } \\
\text { release }\end{array}$ & Pedigree \\
\hline \multicolumn{5}{|l|}{ Bread wheat } \\
\hline Wane & CIMMYT & KARC/EIAR & 2016 & SOKOLL/EXCALIBUR \\
\hline Deka & CIMMYT & KARC/EIAR & 2017 & ATTILA/3 $*$ BCN $* 2 / /$ BAV92/3/KIRITATI/WBLL1/4/DANPHE \\
\hline Kakaba & CIMMYT & KARC/EIAR & 2010 & KIRITATI//SERI/RAYON \\
\hline Ogolcho & CIMMYT & KARC/EIAR & 2012 & WORRAKATTA $/ 2 *$ PASTOR \\
\hline Pavon-76 & CIMMYT & KARC/EIAR & 1982 & $\mathrm{VCM} / / \mathrm{CNO}$ “s”/7 C/3/KAL/BB \\
\hline Kingbird & CIMMYT & KARC/EIAR & 2015 & $\begin{array}{c}\text { TAM200/TUI/6/PVN//CAR422/ANA/5/BOW/CROW//BUC/PVN/ } \\
\text { 3/YR/4/TRAP\# } 1\end{array}$ \\
\hline \multicolumn{5}{|l|}{ Durum wheat } \\
\hline $\begin{array}{l}\text { Donmatio } \\
\text { (D2018) }\end{array}$ & Italy & DZARC/EIAR & 2018 & NA \\
\hline Mangudo & ICARDA & DZARC/EIAR & 2012 & MRF_1/STJ2/3/1718/BT24//KARIM \\
\hline Utuba & ICARDA & DZARC/EIAR & 2015 & Omruf1/Stojocri2/3/1718/BeadWheat24//Karim = Icajihan 42 \\
\hline Alemtena & ICARDA & DZARC/EIAR & 2017 & Icasyr $1 / 3 / \mathrm{Gcn} / / \mathrm{Sti} / \mathrm{Mrb3}$ \\
\hline Ude & CIMMYT & DZARC/EIAR & 2002 & Chen/Altar//Jori69 \\
\hline Mukuye & ICARDA & DZARC/EIAR & 2012 & STJ3//BCR/LKS4/3/TER-3 \\
\hline
\end{tabular}

Note. CIMMYT, ICARDA, KARC, DZARC, and EIAR are International Maize and Wheat Improvement Center, International Center for Agricultural Research in the Dry Areas, Kulumsa Agricultural Research Center, Debre Zeit Agricultural Research Center, and Ethiopian Institute of Agricultural Research, respectively.

2.2. Pot Repacking and Water Management. The 12 wheat varieties were sown in pots with a capacity of 5 liters each $(22 \mathrm{~cm}$ top diameter, $16 \mathrm{~cm}$ bottom diameter, and $18 \mathrm{~cm}$ height). The soil was collected from the nearby site where the experiment was conducted in a rainout shelter at Kulumsa, Ethiopia. The soil was air-dried, sieved to pass through a $2 \mathrm{~mm}$ mesh, and its residual moisture content (17\%) and bulk density $\left(1.05 \mathrm{~g} \mathrm{~cm}^{-3}\right)$ were determined prior to repacking. Each pot was repacked with $4.5 \mathrm{~kg}$ air-dried soil. The repacked soil was saturated with water and kept overnight. The next day, 16 March 2019, a total of 15 and 10 seeds of bread and durum wheat, respectively, were sown in each pot. The germinated wheat was thinned to 10 and 8 plants of bread and durum wheat, respectively, after emergence to meet the recommended seed rate of wheat for sowing $\left(125 \mathrm{~kg} \mathrm{ha}^{-1}\right)$. The numbers of seedlings per pot were attained considering the area of the pot $\left(334 \mathrm{~cm}^{2}\right)$ and the mean kernel weight of 6 bread wheat $(41.08 \mathrm{mg})$ and 6 durum wheat $(54.25 \mathrm{mg})$ varieties. Based on the recommended package for wheat, $0.53 \mathrm{~g}$ nitrogen $(\mathrm{N})$ and $0.50 \mathrm{~g}$ phosphorous (P) fertilizers from urea and triple super phosphate per pot were applied at sowing, which were equivalent to 73 and $30 \mathrm{~kg} \mathrm{~N}$ and $\mathrm{P} \mathrm{ha}^{-1}$, respectively.

The water management under well-watered treatment was equivalent to $100 \%$ field capacity (FC) and was measured according to Khakwani et al. [31]. The $100 \%$ FC was equivalent to replenishing the same amount of water lost in the form of evapotranspiration at a certain period. The water stress was induced by refilling the soil to only $30 \%$ FC. The $100 \%$ FC was calculated considering the weather, soil, and crop properties. The weather variables were used to compute the reference evapotranspiration (ETo). The ETo per period and different development stages of the sown wheat crop in the studied soil and environment were calculated using a decision support computer program developed by FAO called CROPWAT 8.0 [32]. This program uses the FAO Penman-Monteith method [33] for calculating ETo. The daily input weather variables for computing ETo, minimum and maximum temperatures, wind speed, relative humidity, and sunshine hours were accessed from the nearby meteorological station located in the KARC. The remaining input weather variable, daily radiation, was calculated using the FAO CROPWAT 8.0 model [32]. Since there was no established crop coefficient $(\mathrm{Kc})$ for wheat in the study area, the values developed by FAO were used [33]. The crop water requirmenet (CWR) at different periods was found by multiplying Kc values of each crop development stage with the computed ETo $(\mathrm{CWR}=\mathrm{Kc} * \mathrm{ETo})$. The mean monthly weather data and the computed ETo values are summarized Table 2.

The application of water treatments started after germination of the seeds and continued until maturity. The irrigation water requirement for the $100 \% \mathrm{FC}$, which is the amount of water that had to be applied to replenish the crop's evapotranspiration without significant reduction in yield, was computed based on the water requirement of the test crop (CWR) per its stages of growth and weather conditions. The $30 \%$ FC was calculated once the $100 \%$ FC value was obtained. Irrigation water was applied every 4 days since tillering to physiological maturity.

2.3. Evaluation of Morphological Traits. The morphological and physiological data were recorded from the pot experiment conducted at KARC. The morphological traits measured for this experiment included plant height $(\mathrm{PH})$, spike length (SPL), and number of spikelet per spike (NSPS). The measurement of each of the morphological traits was recorded from the randomly selected 3 sample plants from each pot at physiological maturity, and the values were expressed as a mean per each pot. The $\mathrm{PH}$ was measured using a meter scale from the surface of the pot (soil) to apex of the plant excluding awns. The SPL was measured using a meter scale from the base of spike to its tip excluding awns. 
TABLE 2: Weather variables and reference evapotranspiration of wheat in the study area during March-July 2019.

\begin{tabular}{|c|c|c|c|c|c|c|}
\hline Month & Max temp. $\left({ }^{\circ} \mathrm{C}\right)$ & Min temp. $\left({ }^{\circ} \mathrm{C}\right)$ & Relative humidity (\%) & Wind speed $\left(\mathrm{m} \mathrm{s}^{-1}\right)$ & Sunshine (hrs) & ETo $\left(\mathrm{mm} \mathrm{day}^{-1}\right)$ \\
\hline March & 28.4 & 12.8 & 34 & 1.0 & 8.2 & 4.64 \\
\hline April & 26.4 & 13.2 & 51 & 0.7 & 6.2 & 3.83 \\
\hline May & 26.0 & 12.8 & 48 & 1.1 & 8.0 & 4.46 \\
\hline June & 24.2 & 13.1 & 69 & 0.8 & 5.9 & 3.45 \\
\hline July & 22.9 & 12.3 & 65 & 0.5 & 5.0 & 3.13 \\
\hline
\end{tabular}

Note. Max temp. is the average maximum temperature, Min temp. is the average minimum temperature, and ETo is the average total reference evapotranspiration.

The NSPS was counted from the randomly selected 3 plants, and the mean value was taken.

\subsection{Evaluation of Physiological Traits}

2.4.1. Determination of Relative Chlorophyll Content (RCC). After the anthesis stage, the relative amount of chlorophyll present in wheat leaves (chlorophyll index), an indicative parameter to predict nitrogen fertilization in wheat, was measured with a hand-held portable device called SPAD 502 (Konica Minolta, Inc.) on randomly selected 3 sample flag leaves of the plant from each pot. The technique instantly measures the RCC of the leaves by simply clamping the meter over the leaf and obtaining the reading on a scale. The measurement values were expressed as a mean of 3 individual SPAD meter readings per pot.

2.4.2. Determination of Relative Water Content (RWC). On one fully expanded leaf per pot, the RWC was determined according to the procedure of Schonfeld et al. [34]. The leaf from each pot was cut at the base of lamina, preserved within a polyethylene plastic bag and immediately brought to the laboratory. The fresh weight of the leaf was weighed immediately after reaching the laboratory using a sensitive balance (precision $=0.01 \mathrm{~g}$ ), and the turgid weight was measured after saturating the leaf within distilled water for $24 \mathrm{~h}$ at room temperature. After saturating, the leaf was carefully transferred to a tissue paper, and its dry weight was recorded after drying it in an oven at $70^{\circ} \mathrm{C}$ for $24 \mathrm{~h}$. RWC was calculated using the following equation:

$$
\text { Relative water content }(\%)=\frac{(\mathrm{FW}-\mathrm{DW})}{(\mathrm{TW}-\mathrm{DW})} * 100,
$$

where FW, DW, and TW are the fresh weight, dry weight, and turgor weight, respectively.

2.5. Evaluation of Biochemical Traits. The laboratory experiments for the biochemical tests were carried out at Melkassa Agricultural Research Center (MARC). The followings were the biochemical traits tested for wheat.

2.5.1. Proline Determination. The analysis of proline (PRO) content in the leaves was measured by using acid ninhydrin reagent following the method of Bates et al. [35]. In order to examine the amount of PRO content in response to water stress, analysis of leaf samples was performed at the flowering stage after the water stress was induced. Fresh plant sample $(0.5 \mathrm{~g})$ was homogenized with $10 \mathrm{ml}$ of $3 \%$ aqueous sulfosalicylic acid, and the homogenate was filtered using Whatman No. 2 filter paper. The filtrate was then used for the determination of PRO concentration. The $2 \mathrm{ml}$ filtrate was taken and mixed with $2 \mathrm{ml}$ of acid ninhydrin and $2 \mathrm{ml}$ of glacial acetic acid in a test tube. The mixture was allowed to react for $1 \mathrm{~h}$ in a waterbath at $100^{\circ} \mathrm{C}$. Then, it was allowed to be cooled until producing reddish color. The reaction mixture was extracted with $4 \mathrm{ml}$ of toluene, mixed vigorously in a test tube, and stirred for 15-20 seconds until separate layers were formed. The chromophore or upper toluene layer containing the color complex due to PRO ninhydrin reaction was separated from the aqueous phase to another test tube and was warmed at room temperature, and absorbance was read at $520 \mathrm{~nm}$ by a spectrophotometer. The PRO concentration was determined from the standard curve constructed from the known concentration of PRO and was expressed in $\mu \mathrm{mol}$ of proline per gram fresh weight of the leaf and calculated on a fresh weight basis as indicated in the following equation.

Proline content $=\frac{\left[\left(\mu \mathrm{g}_{\text {proline }} \mathrm{ml}^{\mathrm{ml}}\right) *\left(\mathrm{ml} \text { toluene } / 115.5 \mu \mathrm{g}^{-\mu \text { mole }}\right)\right]}{[\mathrm{g} \text { sample } / 5]}$.

where the content of PRO was expressed in units of $\mu \mathrm{mol} \mathrm{g}^{-1}$ fresh weight of leaves $\left(\mu \mathrm{mol} \mathrm{g}^{-1} \mathrm{FW}\right)$.

2.5.2. Total Soluble Sugar (TSS). Total soluble sugar in the leaf samples was determined according to DuBois et al. [36] with some modifications [37]. Reagents used for this analysis was $5 \%$ phenol solution, which was prepared by mixing $5 \mathrm{~g}$ of phenol in $95 \mathrm{ml}$ of double distilled water (DDW), and 90\% ethanol, which was prepared by mixing $90 \mathrm{ml}$ of ethanol and $10 \mathrm{ml}$ of DDW. The fresh leaf material weighing $0.25 \mathrm{~g}$ was kept in $10 \mathrm{ml}$ of $90 \%$ ethanol for $1 \mathrm{~h}$ at $60^{\circ} \mathrm{C}$ in a waterbath. The extract was then filtrated using filter paper into a volumetric flask, and the residue was reextracted. Final volume was made up to $25 \mathrm{ml}$ by adding $90 \%$ ethanol. Then, $1 \mathrm{ml}$ of the aliquot was transferred to the test tube, and $1 \mathrm{ml}$ of $5 \%$ phenol was added to it and mixed thoroughly. Later, $5 \mathrm{ml}$ of $95 \%$ sulfuric acid was added to it and mixed thoroughly by vertical agitation. For exothermic reaction, the test tube was cooled in the air. Absorbance was recorded at $490 \mathrm{~nm}$ on a spectrophotometer, and soluble sugar was calculated from the standard glucose graph. The TSS was calculated using the following equation: 


$$
\text { Total soluble sugar }\left(\frac{\mathrm{mg}}{\mathrm{g}}\right)=\frac{\text { Sugar value from graph }(\mu \mathrm{g})}{\text { Aliquot sample used }} * \frac{\text { Total volume of extract }}{\text { Weight of sample }} * 100
$$

2.6. Data Analysis. The wheat physiological, morphological, and biochemical data were subjected to two-way analysis of variance (ANOVA) using the Statistical Analysis System (SAS) version of 9.0 (SAS Institute Inc., Cary NC, USA). Means comparison for treatments with significant effects was performed using the least significant difference test at $5 \%$. Simple correlation analysis between traits was also carried out using the same statistical tool. The graphs were plotted using Microsoft Excel 2010 (Microsoft ${ }^{\oplus}$ Corp., Redmond, Washington, USA).

\section{Results and Discussion}

The analysis of variance (ANOVA) revealed that there were significant differences $(p<0.001)$ among the wheat varieties in terms of the studied traits except for plant height and relative water content (Table 3 ). The influence of water stress was also highly significant $(p<0.001)$ on all the measured variables. The results further indicated that there were no significant interaction effects between variety and water stress for all the studied traits (Table 3). Thus, only the main effects were presented and discussed.

\subsection{Water Management}

3.1.1. Morphological Traits of Wheat. The influence of water stress was highly significant $(p<0.001)$ and reduced the plant height $(\mathrm{PH})$, spike length (SPL), and number of spikelet per spike (NSPS) (Table 4). Overall, the mean PH of wheat was very significantly reduced under water stress $(48 \mathrm{~cm})$ compared to the well-watered treatment $(65 \mathrm{~cm})$, which accounted for a decrease of $26 \%$. The stunted growth in wheat varieties could attribute to more leaf senescence, decrease in relative turgidity, and dehydration of the protoplasm, which in turn is associated to the loss of turgor as well as reduced division, expansion, and enlargement of cells [38]. The current result is in agreement with Mushtaq et al. [39] who reported reduction in $\mathrm{PH}$ of wheat from $77 \mathrm{~cm}$ to $61.66 \mathrm{~cm}$ when irrigation was skipped at the tillering stage of crop growth. Reduction in $\mathrm{PH}$ due to water stress was also reported by Gupta et al. [40] who evaluated drought tolerance on 2 spring wheat varieties. Reduction in plant height of $14.7 \%$ caused by drought was also identified by Bayoumi et al. [41].

The SPL of wheat varieties was found shorter under water-stressed treatment $(5 \mathrm{~cm})$ in contrast to well-watered treatment $(5.5 \mathrm{~cm})$ (Table 4$)$, which resulted in $9 \%$ reduction. The difference in SPL is governed by genetic makeup of varieties and environmental effects [42]. This result is in agreement with Jemal et al. [43] who reported $9 \%$ decline in spike length with increasing water stress. Memon et al. [44] also reported a similar effect of deficit irrigation on spike length in wheat. Compared to the well-watered treatment (12), the mean NSPS under water stress (9) was reduced by
23\% (Table 4). Significantly decreased number of grains (kernels) per spike caused by water stress was also reported by Rahim et al. [45].

3.1.2. Physiological Characteristics of Wheat. The water scarcity resulted in significantly lower $(p<0.001)$ relative water content (RWC) under water-stressed condition (63.54\%) compared to the well-watered treatment (75.51\%) indicating the plant water status under drought condition was inferior by $16 \%$ (Table 4). During water stress, the water balance of plants is disrupted, as a result of which the RWC and water potential of leaves decrease [46]. The RWC values in well-watered and water stress treatments were in consistent with Abdul Raziq et al. [47] who reported $36.7 \%$ reduction in the RWC of the leaves due to water deficit. Decreased RWC with water stress in all the tested varieties was also reported in common bean [48]. Changes in the RWC of leaves are considered as a sensitive indicator of drought stress and more useful integrator of plant water balance than the leaf water potential [49].

The water stress (41.62 SPAD units) resulted in $11 \%$ reduction in the relative chlorophyll content (RCC) in contrast to the well-watered treatment (46.83 SPAD units) (Table 4). The decline in RCC under the water stress treatment could be attributed to the destruction of the chlorophyll and inhibition of its synthesis. Several researchers including Lessani and Mojtahedi [50] reported the damage of leaf pigments because of water scarcity. This is also supported by the findings of Sikuku et al. [51] who noted the inhibition of chlorophyll synthesis and inability of wheat to withstand water scarcity. A further reason for the diminution in RCC in response to water scarcity was the production of reactive oxygen species (ROS) such as $\mathrm{O}^{2-}$ and $\mathrm{H}_{2} \mathrm{O}_{2}$ due to drought or heat stress, which lead to lipid peroxidation and thus chlorophyll destruction [52]. Also, with decreasing chlorophyll content due to the change of the color of leaf from green into yellow, the reflectance of the incident radiation is increased [53]. The presented results are in agreement with the work of Araus et al. [54].

Higher relative chlorophyll content (RCC) in plants' leaves is a desirable characteristic because it indicates a low degree of photo inhibition of photosynthetic apparatus, therefore, reducing carbohydrate losses for grain development [55]. Chlorophyll is one of the major components of chloroplast, which helps for photosynthesis [38]. The RCC has a positive relationship with photosynthetic rate, while flag leaf chlorophyll content is an indicator of the photosynthetic activity and its stability for the conjugation of assimilate biosynthesis. Several researchers have successfully employed this trait for screening and selection of drought tolerance in wheat cultivars [56]. Thus, wheat cultivars with higher RCC can be considered as potential candidates for the droughtprone environments. 
TABLE 3: ANOVA table for the influence of varieties and water management on morphological, physiological, and biochemical characteristics of wheat.

\begin{tabular}{|c|c|c|c|c|c|c|c|}
\hline $\begin{array}{l}\text { Sources of } \\
\text { variation }\end{array}$ & $\begin{array}{c}\text { Plant } \\
\text { height } \\
(\mathrm{cm})\end{array}$ & $\begin{array}{l}\text { Spike } \\
\text { length } \\
(\mathrm{cm})\end{array}$ & $\begin{array}{l}\text { No. of } \\
\text { spikelet } \\
\text { spike }^{-1}\end{array}$ & $\begin{array}{l}\text { Relative water } \\
\text { content }(\%)\end{array}$ & $\begin{array}{l}\text { Relative chlorophyll } \\
\text { content (SPAD unit) }\end{array}$ & $\begin{array}{l}\text { Proline content } \\
\left.\quad(\mu \mathrm{mol} \mathrm{g})^{-1}\right)\end{array}$ & $\begin{array}{l}\text { Total soluble } \\
\text { sugar }(\mathrm{mg} / \mathrm{g})\end{array}$ \\
\hline Rep & * & ns & ns & $* * *$ & ns & ns & ns \\
\hline Variety $(\mathrm{V})$ & ns & $* * *$ & $* * *$ & ns & $* * *$ & $* * *$ & $* * *$ \\
\hline $\begin{array}{l}\text { Water } \\
\text { management } \\
(\mathrm{WM})\end{array}$ & $* * *$ & $* * *$ & $* * *$ & $* * *$ & $* * *$ & $* * *$ & $* * *$ \\
\hline $\mathrm{V} * \mathrm{WM}$ & ns & ns & ns & ns & ns & ns & ns \\
\hline Mean & 56.23 & 5.25 & 10.69 & 69.52 & 44.22 & 3.43 & 48.34 \\
\hline $\mathrm{CV}$ & 8.07 & 10.8 & 9.4 & 15.54 & 9.64 & 17.99 & 5.28 \\
\hline $\mathrm{LSD}_{\mathrm{V}}$ & 5.27 & 0.66 & 1.16 & 12.56 & 4.95 & 0.71 & 2.96 \\
\hline $\mathrm{LSD}_{\mathrm{WM}}$ & 2.15 & 0.27 & 0.47 & 5.12 & 2.02 & 0.29 & 1.21 \\
\hline
\end{tabular}

Note. ns, not significant at $p<0.05$, ${ }^{*}$ significant at $p<0.01$, and $* * *$ significant at $p<0.001$. CV, coefficient of variation; LSD $_{V}$, list significant difference of varieties; $\mathrm{LSD}_{\mathrm{WM}}$, list significant difference of water management.

TABLE 4: Mean comparison of selected morphological, physiological and biochemical characteristics of wheat varieties under well-watered and water stress conditions.

\begin{tabular}{lccccccc}
\hline $\begin{array}{l}\text { Sources of } \\
\text { variation }\end{array}$ & $\begin{array}{c}\text { Plant height } \\
(\mathrm{cm})\end{array}$ & $\begin{array}{c}\text { Spike } \\
\text { length }(\mathrm{cm})\end{array}$ & $\begin{array}{c}\text { No. of spikelet } \\
\text { spike }^{-1}\end{array}$ & $\begin{array}{c}\text { Relative water } \\
\text { content }(\%)\end{array}$ & $\begin{array}{c}\text { Relative chlorophyll } \\
\text { content (SPAD unit })\end{array}$ & $\begin{array}{c}\text { Proline } \\
\left(\mu \mathrm{mol} \mathrm{g}^{-1}\right)\end{array}$ & $\begin{array}{c}\text { Total soluble } \\
\text { sugar }(\mathrm{mg} / \mathrm{g})\end{array}$ \\
\hline Well watered & $64.6^{\mathrm{a}}$ & $5.5^{\mathrm{a}}$ & $12.0^{\mathrm{a}}$ & $75.51^{\mathrm{a}}$ & $46.83^{\mathrm{a}}$ & $3.01^{\mathrm{b}}$ & $46.84^{\mathrm{b}}$ \\
Water stress & $47.9^{\mathrm{b}}$ & $5.0^{\mathrm{b}}$ & $9.29^{\mathrm{b}}$ & $63.54^{\mathrm{b}}$ & $41.62^{\mathrm{b}}$ & $3.85^{\mathrm{a}}$ & $49.84^{\mathrm{a}}$ \\
Mean & 56.23 & 5.25 & 10.69 & 69.52 & 44.22 & 3.43 & 48.34 \\
CV & 8.07 & 10.8 & 9.4 & 15.54 & 9.64 & 17.99 & 5.28 \\
LSD $_{[0.05]}$ & 2.15 & 0.27 & 0.47 & 5.12 & 2.02 & 0.29 \\
\hline
\end{tabular}

$\mathrm{CV}$, coefficient of variation; $\mathrm{LSD}_{\mathrm{WM}}$, list significant difference of water management.

3.1.3. Biochemical Characteristics of Wheat. The influence of water scarcity was highly significant $(p<0.001)$ on the production of proline (PRO) and total soluble sugar (TSS) in wheat varieties (Table 3). The results revealed $28 \%$ increases in PRO synthesis in wheat in response to water stress $\left(3.85 \mu \mathrm{mol} \mathrm{g}^{-1}\right)$ as compared to the well-watered condition $\left(3.01 \mu \mathrm{molg}^{-1}\right)$ (Table 3). This implies that the tested varieties produced significantly higher amount of PRO under the water stress condition as a mitigation strategy to cope up with the drought. The accumulation of PRO in plants tissues is a clear indication of their inherent ability for tolerance against environmental stress, particularly in plants under drought stress. The PRO accumulation may also be part of the stress signal influencing adaptive responses [57]. Therefore, the more the PRO, the better the ability of plants to withstand water stress, which is one of the most common compatible osmolytes in drought-stressed plants.

Similarly, the ANOVA revealed $6 \%$ rise in the amount of total soluble sugar (TSS) under water stress $\left(49.84 \mathrm{mg} \mathrm{g}^{-1}\right)$ than well-watered condition $\left(46.84 \mathrm{mg} \mathrm{g}^{-1}\right)$. This also implies that the tested varieties under water stress treatment produced significantly higher amount of TSS in response to the water scarcity as a stress escaping strategy. The leaf osmotic adjustment through the synthesis of soluble sugars has been a well-known mechanism to withstand water stress in many plants $[58,59]$. The synthesis of soluble sugars plays a great role in osmotic adjustment for water scarcity. The osmotic cell potential in plants can be adjusted by increasing the concentration of TSS, which can decrease water potential of cells without inhibiting the function of the enzyme and does not reduce turgidity of the cell. Increased concentration of sugar because of water scarcity helps to maintain the stability of the membrane, which in turn prevents and protects membrane fusion and keeps protein so as to stay functional $[59,60]$. According to Zhang et al. [26], solutes accumulated during stress serve as an aid to cope with the existing condition. The current result is in accordance with Hou et al. [61] who reported that the sugar content in the leaves of the plant could increase under drought conditions.

\subsection{Morphological, Physiological, and Biochemical Characteristics of Wheat Varieties}

3.2.1. Morphological Traits of Wheat Varieties. Given the nonsignificant interaction effects (Table 3), the pooled mean values for the variables of wheat varieties measured over the two water management practices have been presented and discussed. The ANOVA indicated that there were marginally significant $(p=0.05)$ differences among the tested wheat varieties in plant height $(\mathrm{PH})$ (Table 3; Figure 1). The tallest plant $(61.1 \mathrm{~cm})$ was recorded from the Ude variety. However, this result was statistically similar to Ogolcho $(58.4 \mathrm{~cm})$, Deka $(58.2 \mathrm{~cm})$, Mangudo $(58.2 \mathrm{~cm})$, Pavon-76 $(56.4 \mathrm{~cm})$, and Utuba $(56.3 \mathrm{~cm}$ ) varieties (Figure 1). The shortest wheat variety in this study was Donmatio $(50.9 \mathrm{~cm})$, which was inferior compared to the aforementioned varieties (Figure 1). Donmatio was found the shortest amongst the tested varieties under optimum 


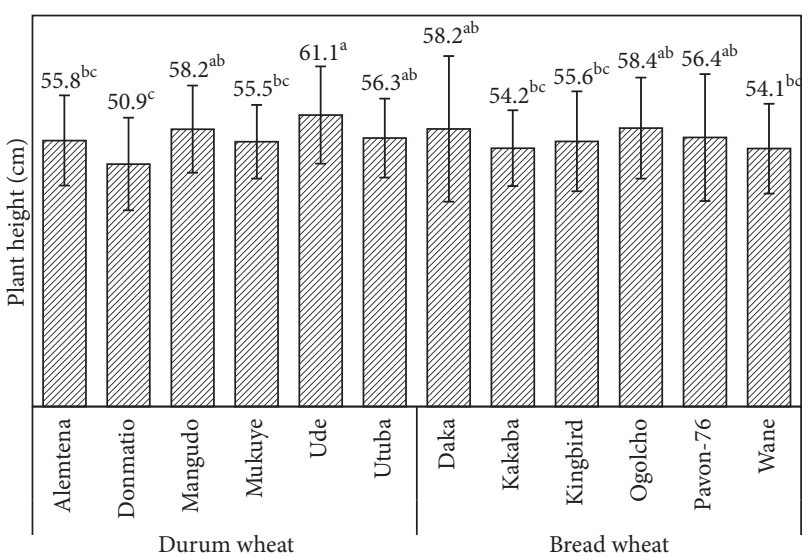

FIGURE 1: Means for the main effects of variety and water stress on the plant height of durum and bread wheat in Kulumsa.

condition too (data not shown). Nevertheless, this result was found statistically similar to Wane $(54.1 \mathrm{~cm})$, Kakaba $(54.2 \mathrm{~cm})$, Mukuye $(55.5 \mathrm{~cm})$, Kingbird $(55.6 \mathrm{~cm})$, and Alemtena $(55.8 \mathrm{~cm})$ varieties. The difference in $\mathrm{PH}$ of the varieties could be attributed to the difference in their genetic makeup [43] and environmental factors such as water scarcity [42], which results in the decline of the cell enlargement and more leaf senescence [38].

The results further revealed that the tested wheat varieties highly significantly $(p<0.001)$ contrasted in spike length (SPL) (Table 3; Figure 2). The longest and statistically superior SPL $(6.9 \mathrm{~cm})$ was recorded from Ogolcho variety (Figure 2). Though statistically lesser compared to the Ogolcho variety, the next longest SPL was recorded from Kingbird $(6.2 \mathrm{~cm})$, Deka $(6.1 \mathrm{~cm})$, Pavon-76 $(5.9 \mathrm{~cm})$, and Kakaba $(5.6 \mathrm{~cm})$ varieties, which were statistically similar to each other. The shortest SPL was recorded from Mukuye variety $(4.2 \mathrm{~cm})$; however, it was statistically similar to Ude $(4.4 \mathrm{~cm})$, Alemtena $(4.5 \mathrm{~cm})$, Utuba $(4.5 \mathrm{~cm})$, Mangudo $(4.7 \mathrm{~cm})$, and Wane $(4.9 \mathrm{~cm})$ varieties. Compared to Ogolcho, the SPL of Mukuye, Ude, Alemtena, Utuba, Mangudo, and Wane varieties was found shorter by $39 \%, 37 \%, 36 \%$, $35 \%, 32 \%$, and $29 \%$, respectively.

Likewise, there were very highly significant $(p<0.001)$ differences among the tested varieties regarding the number of spikelet per spike (NSPS) (Table 3; Figure 3). The Donmatio variety gave the highest NSPS (12.2); however, this result was statistically similar to Alemtena (12.0), Kingbird (11.4), Mangudo (11.2), and Deka (11.1) varieties (Figure 3). The lowest NSPS was recorded from Wane (8.6) variety, which was found statistically similar to Kakaba (8.8) variety (Figure 3). Wane and Kakaba varieties yielded $30 \%$ and $28 \%$ lower NSPS in contrast to the Donmatio variety. The number of spikelet per spike is an important yield component since it determines the potential of wheat yield.

\subsubsection{Physiological Characteristics of Wheat Varieties.} The results showed that the relative chlorophyll content (RCC) differed significantly $(p<0.001)$ among the tested varieties (Table 3). The highest RCC (49.6 SPAD unit) was recorded from

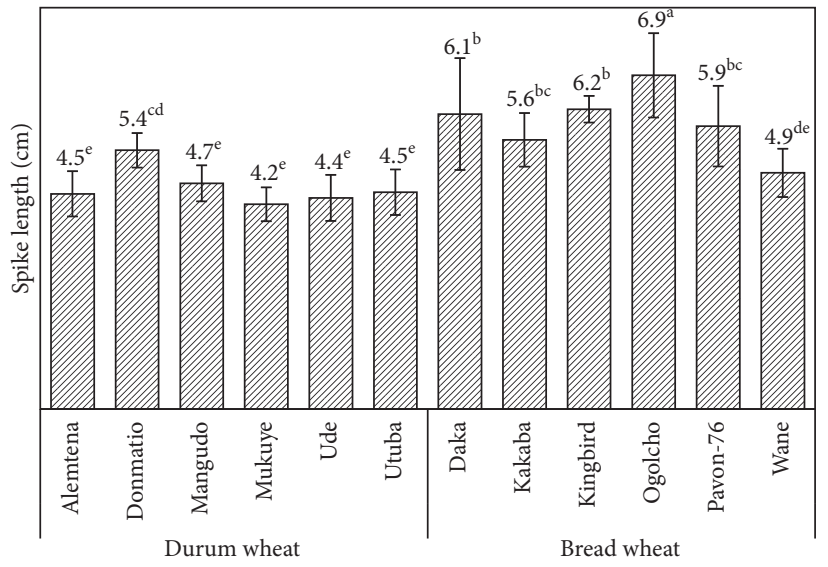

Figure 2: Means for the main effects of variety and water stress on the spike length of durum and bread wheat in Kulumsa.

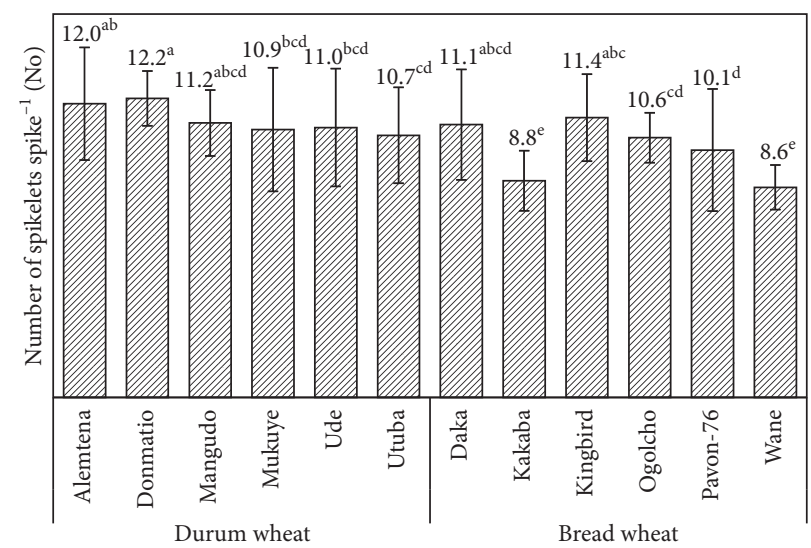

Figure 3: Means for the main effects of variety and water stress on the number of spikelet per spike of durum and bread wheat in Kulumsa.

the Mangudo variety (Figure 4). Statistically equivalent RCC was also noted from the Donmatio, Alemtena, Mukuye, Utuba, and Ude varieties, which had values of 49.1, 47.6, 47.0, 46.5, and 44.67 SPAD units, respectively (Figure 4). Conversely, the lowest RCC was recorded from Deka and Pavon-76 varieties with values of 39.4 SPAD unit, which were also statistically similar to Kakaba (40.9 SPAD unit), Kingbird (41.2 SPAD unit), Ogolcho (42.5 SPAD unit), and Wane (42.9 SPAD unit) varieties. Compared to the Mangudo variety, the RCC measured from the Deka, Pavon-76, Kakaba, Kingbird, Ogolcho, and Wane varieties was lesser by $21 \%, 21 \%, 17 \%, 17 \%, 14 \%$, and $13 \%$, respectively.

Considering the relative water content (RWC), ANOVA did not present statistically significant differences $(p<0.05)$ among the tested varieties (Table 3 ). This implies that the abilities of the tested varieties in maintaining their RWC by absorbing water from the soil and curtailing water loss through their stomata were more or less similar.

3.2.3. Biochemical Characteristics of Wheat Varieties. The ANOVA presented highly significant $(p<0.001)$ differences among the tested varieties concerning the production of proline 


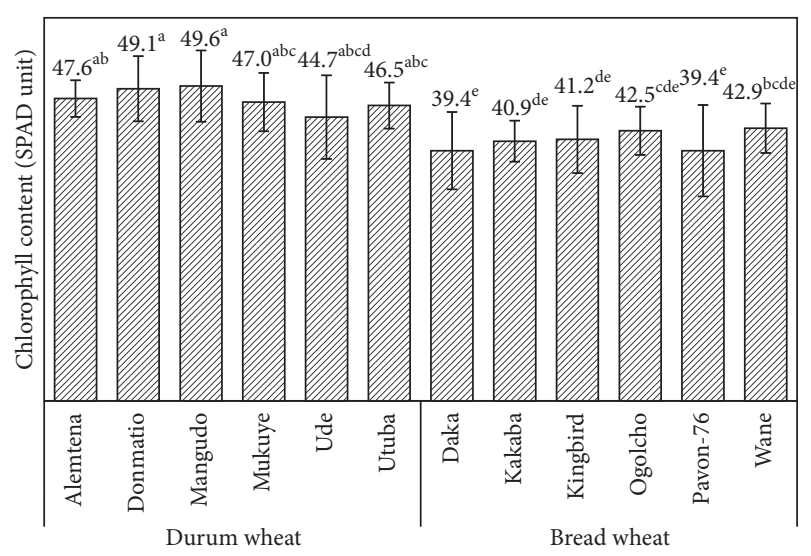

FIGURE 4: Means for the main effects of variety and water stress on the relative chlorophyll content of durum and bread wheat in Kulumsa.

(PRO) (Table 3). Utuba variety yielded the highest PRO $\left(4.78 \mu \mathrm{molg}^{-1}\right)$ followed by Alemtena $\left(4.65 \mu \mathrm{molg}^{-1}\right)$, Donmatio $\left(4.37 \mu \mathrm{mol} \mathrm{g}^{-1}\right)$, and Mukuye $\left(4.28 \mu \mathrm{mol} \mathrm{g}^{-1}\right)$ varieties (Figure 5). The lowest PRO was synthesized by Deka variety $\left(2.22 \mu \mathrm{mol} \mathrm{g}^{-1}\right)$. This result, however, was found statistically equivalent to Ogolcho $\left(2.25 \mu \mathrm{mol} \mathrm{g}^{-1}\right)$, Wane $\left(2.75 \mu \mathrm{mol} \mathrm{g}^{-1}\right)$, and Pavon-76 $\left(2.9 \mu \mathrm{molg}^{-1}\right)$ varieties (Figure 5). Overall, the later varieties yielded $54 \%, 53 \%, 42 \%$, and $39 \%$ reductions in the PRO content, respectively, compared to Utuba variety. The synthesis of high content of PRO in wheat varieties might increase their ability for osmotic regulation against the protection from the damage of soil water deficits. Furthermore, PRO is a compatible solute, which plays a great role as an enzyme-stabilizing agent. Thus, it has the ability of osmotic balance in the cytoplasm and vacuole to stabilize subcellular structure and for protection of membrane and proteins from oxidative damage during water stress [62-64]. PRO is one of the osmoprotectants that is accumulated in many crops in response to different kinds of stresses including drought [65]. Given higher level of PRO and TSS synthesis, in plant leaves, Utuba, Alemtena, and Donmatio varieties among durum wheat and Ogolcho, Kakaba, and Kingbird varieties among bread wheat were found to be relatively resistant to waterstressed environments compared to others.

The ANOVA exhibited that the tested varieties varied highly significantly $(p<0.001)$ in total soluble sugar (TSS) production (Table 3; Figure 6). Ogolcho yielded the highest TSS $\left(51.32 \mathrm{mgg}^{-1}\right)$ followed by Utuba $\left(51.05 \mathrm{mgg}^{-1}\right)$, Alemtena $\left(49.6 \mathrm{mg} \mathrm{g}^{-1}\right), \quad$ Kakaba $\left(49.62 \mathrm{mgg}^{-1}\right)$, and Kingbird $\left(49.03 \mathrm{mg} \mathrm{g}^{-1}\right)$ varieties (Figure 6). The lowest TSS was manufactured by Mangudo variety $\left(44.1 \mathrm{mgg}^{-1}\right)$, which was comparable to Mukuye (46.87 $\mathrm{mgg}^{-1}$ ) and Pavon-76 (46.9 mg g ${ }^{-1}$ ) varieties (Figure 6). Overall, these varieties yielded $8.6-14 \%$ reductions in the TSS production compared to Ogolcho variety.

\subsection{Wheat Species as Influenced by Water Management.} Pooled over the tested species, bread and durum wheat significantly differed in spike length, number of seeds spike ${ }^{-1}$, relative chlorophyll, and proline contents when exposed to water stress (Table 5). Generally, durum wheat tended to have a better capacity to undertake mitigation strategy to cope up with

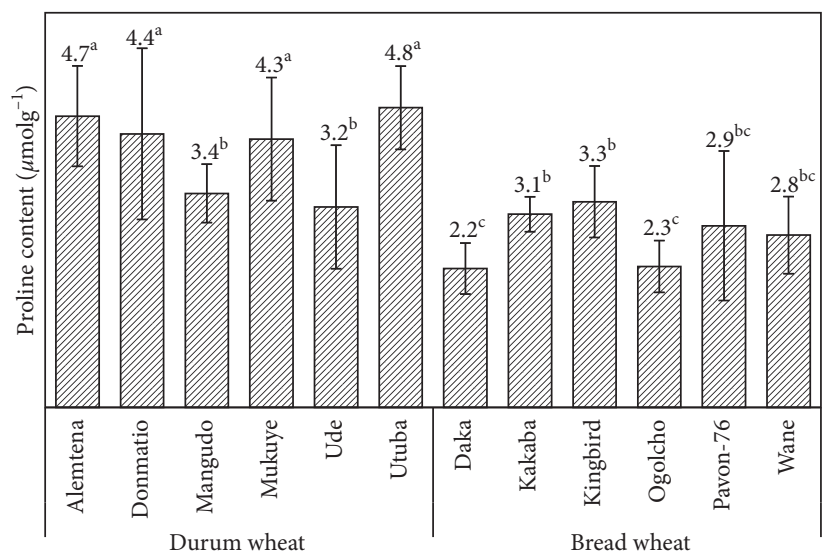

Figure 5: Means for the main effects of variety and water stress on the proline content of durum and bread wheat in Kulumsa.

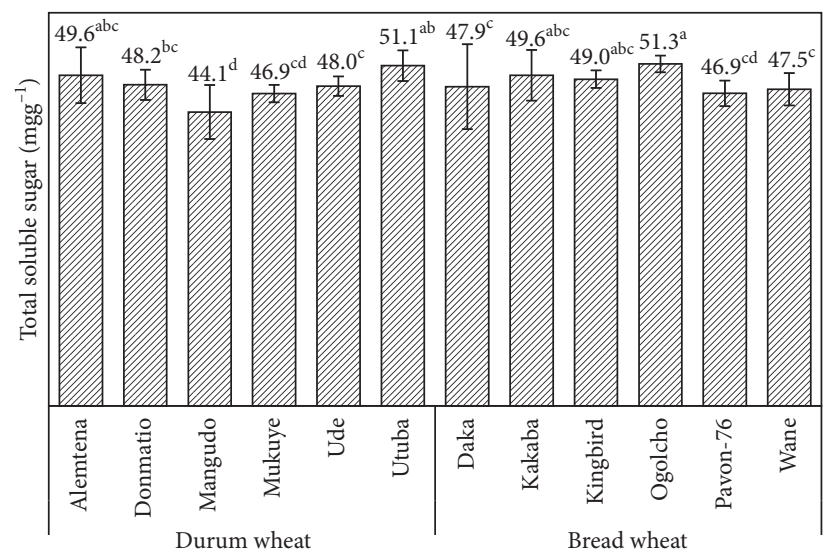

FIGURE 6: Means for the main effects of variety and water stress on the total soluble sugar content of durum and bread wheat in Kulumsa.

drought compared to bread wheat. This is because the largest number of spikelets spike ${ }^{-1}$ (11), higher relative chlorophyll (47.4 SPAD unit), and proline $\left(4.1 \mu \mathrm{molg}^{-1}\right)$ contents were recorded in durum than bread wheat. The larger the number of spikelets spike ${ }^{-1}$, the higher is the potential yield of wheat [66]. Similarly, the higher the RCC in the leaves, the higher is the capacity of the plant to synthesis food and consequently boost yield compare to the plant with lower RCC [67]. Plants with higher proline content in their body develop resistance to cope up with water stress and result in better yield compared to other plants with lower proline content [68]. The longer spike length $(5.9 \mathrm{~cm})$, however, was obtained in bread than durum wheat (Table 5). The ANOVA further indicated that bread and durum wheat species did not significantly differ in plant height, relative water content, and total soluble sugar under water stress condition (Table 5), which implies that they have a more or less similar capacity in retaining RWC by extracting moisture from the soil and synthesis of total soluble sugar.

3.4. Correlation Analysis among Traits. The result of correlation analysis among morphological, physiological, and biochemical traits of wheat as influenced by the genotype and water scarcity is presented in Table 6 . The result showed 
TABLE 5: Mean comparison of selected morphological, physiological, and biochemical characteristics of wheat species under well-watered and water stress conditions.

\begin{tabular}{|c|c|c|c|c|c|c|c|}
\hline $\begin{array}{l}\text { Species of } \\
\text { wheat }\end{array}$ & $\begin{array}{l}\text { Plant height } \\
(\mathrm{cm})\end{array}$ & $\begin{array}{l}\text { Spike length } \\
(\mathrm{cm})\end{array}$ & $\begin{array}{l}\text { No. of seeds } \\
\text { spike }^{-1}\end{array}$ & $\begin{array}{c}\text { Relative water } \\
\text { content }(\%)\end{array}$ & $\begin{array}{l}\text { Relative chlorophyll } \\
\text { content (SPAD unit) }\end{array}$ & $\begin{array}{c}\text { Proline } \\
\left(\mu \mathrm{mol} \mathrm{g}^{-1}\right)\end{array}$ & $\begin{array}{l}\text { Total soluble } \\
\text { sugar }(\mathrm{mg} / \mathrm{g})\end{array}$ \\
\hline Bread wheat & 56.2 & $5.9^{\mathrm{a}}$ & $10.1^{\mathrm{b}}$ & 69.2 & $41.0^{\mathrm{b}}$ & $2.8^{\mathrm{b}}$ & 48.7 \\
\hline $\begin{array}{l}\text { Durum } \\
\text { wheat }\end{array}$ & 56.3 & $4.6^{\mathrm{b}}$ & $11.3^{\mathrm{a}}$ & 69.8 & $47.4^{\mathrm{a}}$ & $4.1^{\mathrm{a}}$ & 47.97 \\
\hline Mean & 56.2 & 5.3 & 10.7 & 69.5 & 44.2 & 3.4 & 48.3 \\
\hline $\mathrm{CV}$ & 8.8 & 14.1 & 12.5 & 15.2 & 9.2 & 23.6 & 6.4 \\
\hline $\mathrm{LSD}_{(0.05)}$ & ns & 0.35 & 0.63 & ns & 1.91 & 0.38 & ns \\
\hline
\end{tabular}

Note. ns, not significant at $p<0.05$. CV, coefficient of variation; $\operatorname{LSD}_{(0.05)}$, list significant difference of species.

TABLE 6: Correlation coefficients for morphological, physiological, and biochemical parameters of wheat as affected by genotype and water management.

\begin{tabular}{lcccccc}
\hline Traits & PH & SPL & NSPS & RWC & RCC & PRO \\
PH & 1 & $0.32^{* *}$ & $0.69^{* * *}$ & $0.35^{* *}$ & $0.39^{* * *}$ & $-0.44^{* * *}$ \\
SPL & & 1 & $0.23^{\text {ns }}$ & $0.05^{\text {ns }}$ & $-0.17^{\mathrm{ns}}$ & $-0.54^{* * *}$ \\
NSPS & & 1 & $0.27^{*}$ & $0.53^{* * *}$ & $-0.13^{\mathrm{ns}}$ & $-0.05^{\mathrm{ns}}$ \\
RWC & & & 1 & $0.25^{*}$ & $-0.35^{* *}$ \\
RCC & & & & 1 & $-0.05^{\mathrm{ns}}$ & $-0.39^{* * *}$ \\
PRO & & & & & $-0.31^{* *}$ \\
TSS & & & & & 1 \\
\hline
\end{tabular}

Note. ns, not significant at $p<0.05 .{ }^{*}$ Significant at $p<0.05,{ }^{*}{ }^{*}$ significant at $p<0.01$, and ${ }^{*} * *$ significant at $p<0.001$. PH, SPL, NSPS, RWC, RCC, PRO, and TSS are the plant height, spike length, number of spikelet per spike, relative water content, proline content, and total soluble sugar contents, respectively.

that plant height strongly and positively correlated with number of spikelet per spike (0.69), relative chlorophyll content (0.39), relative water content $(0.35)$, and spike length (0.32) (Table 6). The result further revealed that significant negative correlation coefficients were found between leaf proline content $(0.44)$ and total soluble sugar $(0.37)$ ( $\mathrm{Ta}-$ ble 6 ). The tall wheat varieties were reported to be more tolerant to postanthesis drought stress because of their capability to partition more stem reserves towards grain filling (Butler et al., 2005) [69]. This depicts that as the $\mathrm{PH}$ increased, the NSPS, RCC, RWC, and SPL also increased correspondingly. This demonstrated that PRO and TSS decreased as the $\mathrm{PH}$ increased.

The uppermost inverse correlation (0.54) during this study was attained between SPL and PRO (Table 6). Highly significant and positive correlation coefficients were found between NSPS and RCC (0.53). The relation between NSPS and RWC (0.27) was also found positively significant. Moderately but negatively significant relation (0.35) was also obtained between NSPS and TSS (Table 6). The correlation of RWC was highly significant but negatively correlated with TSS (0.39), and the relation between RWC and RCC (0.25) was also found positively significant. Highly significant $(p<0.01)$ and opposite correlation was also observed between RCC and TSS (0.31). Except for PRO and SPL, all the traits were highly significant but negatively correlated with TSS.

\section{Conclusions}

The current results showed that water scarcity significantly influenced all the measured traits, while traits linked to morphology, physiology, and biochemistry of the wheat were more influenced by the variety. The results revealed $28 \%$ and $6 \%$ increases in proline and total soluble sugar synthesis, respectively, in wheat in response to water scarcity. The differences in the synthesis of proline and total soluble sugar with an increase in water scarcity among the selected wheat varieties showed the diverse ability of the tested varieties to cope up with drought. Utuba, Alemtena, and Donmatio varieties among durum wheat and Ogolcho, Kakaba, and Kingbird varieties among bread wheat were found to have better capacity to endure water stress by synthesizing more proline and total soluble sugar as mitigation strategies. The plant water status and relative chlorophyll content under water scarcity were reduced by $16 \%$ and $11 \%$, respectively. Compared to the well-water treatment, the mean plant height, spike length, and number of spikelet per spike under water stress were reduced by $26 \%$, $9 \%$, and $23 \%$, respectively. The results further revealed that both bread and durum wheat varieties differed significantly with respect to all the measured variable expect for plant height and relative water content. Overall, durum wheat was found to have a better capacity than bread wheat to withstand water stress through biochemical changes. Thus, except for the plant height and relative water content, the other morphological, physiological, and biochemical parameters could be used as effective indicators to identify tolerant wheat varieties in the water-limited environments. Moreover, the relative effectiveness of selection could be better when two or more traits are considered than using single trait as an independent factor. The dependability of the observed traits for the selection of tolerant wheat varieties for specific area could be recommended to be verified under 
different environmental conditions to solve problems related to water scarcity. The results of this investigation could also provide usable genetic variability for wheat yield improvement and would be of great importance in the selection of appropriate wheat varieties as well as for selection of desirable parents for the breeding program to develop the wheat varieties resistant to drought stress conditions.

\section{Data Availability}

The data used to support the findings of this study are available from the corresponding author upon request.

\section{Conflicts of Interest}

The authors declare that they have no conflicts of interest.

\section{Acknowledgments}

The authors thank Melkassa Agricultural Research Centre for their technical expertise and support during the research period. The authors also gratefully acknowledge Kulumsa and Debre Zeit Agricultural Research Centres for supplying bread and durum wheat seeds, respectively. Their thanks extend to Dr. Berhanu Fenta and Mekuria Temtme for their kind cooperation and encouragement while conducting this work.

\section{References}

[1] H. K. Bekele, H. Verkuij, W. Mwangi, and D. Tanner, Adaptation of Improved Technologies in Adaba and Dodola Weredas of the Bale Highland Ethiopia, International Maize and Wheat Improvement Centre (CIMMYT) and Ethiopian Agricultural Research Organization (EARO), Addis Ababa, AB, Ethiopia, 2000.

[2] CSA (Central Statistics Authority), "Ethiopian agricultural sample environmental the preliminary results of area, production and yield of temporary crop (Meher season private holding)," 2018.

[3] A. Dereje, B. Maru, T. Diress, and H. Mitiku, "Transplanting sorghum as a means of ensuring food security in low rainfall sorghum growing areas of northern Ethiopia," 2007.

[4] M. Lum, M. Hanafi, Y. Rafii, and A. Akmar, "Effect of drought stress on growth, proline and antioxidant enzyme activities of upland rice," Journal of Animal \& Plant Science, vol. 24, pp. 1487-1493, 2014.

[5] G. Kidane, D. Alemnesh, and M. Meshack, "Agriculturalbased livelihood systems in drylands context of climate change: inventory of adaptation practices and technologies of Ethiopia," 2010.

[6] United Nations Population Division, "World Population Prospects: 2018 Revision," 2018.

[7] CSA (Central Statistics Authority), "Report on area and production of crops (private peasant holdings, Meher season)," 2008.

[8] X. Pan, Y. Wang, G. Wang, Q. Cao, and J. Wang, "Relationship between growth redundancy and size inequality in spring wheat populations mulched with clear plastic film," Acta PhytoecolSinica, vol. 26, pp. 177-184, 2002.

[9] H. Hisdal and L. M. Tallaksen, "Estimation of regional meteorological and hydrological drought characteristics: a case study for Denmark," Journal of Hydrology, vol. 281, no. 3, pp. 230-247, 2003.

[10] Z. Tadele, "Raising crop productivity in Africa through intensification," Agronomy, vol. 7, no. 1, p. 22, 2017.

[11] M. M. Chaves, J. S. Pereira, J. Maroco et al., "How plants cope with water stress in the field? Photosynthesis and growth," Annals of Botany, vol. 89, no. 7, pp. 907-916, 2002.

[12] Y. Osakabe, K. Osakabe, K. Shinozaki, and L. S. P. Tran, "Response of plants to water stress," Frontiers in Plant Science, vol. 5, no. 86, pp. 1-8, 2014.

[13] M. H. Sangtarash, "Responses of different wheat genotypes to drought stress applied at different growth stages," Pakistan Journal of Biological Sciences, vol. 13, no. 3, pp. 114-119, 2010.

[14] S. Basu, V. Ramegowda, A. Kumar, and A. Pereira, "Plant adaptation to drought stress," F1000 Report, vol. 5, pp. 1-10, 2016.

[15] J. Beltrano and G. R. Marta, "Improved tolerance of wheat plants (Triticum aestivumL.) to drought stress and rewatering by the arbuscular mycorrhizal fungus Glomus claroideum: effect on growth and cell membrane stability," Journal of Brazilian Social Plant Physiology, vol. 67, pp. 569-572, 2008.

[16] IBC (Institute of Biodiversity Conservation, "Ethiopia: third country report on the state of plant genetic resources for food and agriculture," 2012.

[17] K. Gemechu, B. Endashaw, I. Muhammad, D. Kifle, and A. Getinet, "Challenges associated with crop breeding for adaptation to drought-prone environments," Ethiopian Journal of Agricultural Science, vol. 27, no. 1, pp. 1-4, 2017.

[18] A. Atilaw and L. Korbu, "Recent development in seed systems of Ethiopia," Improving Farmers' Access to Seed, vol. 32, pp. 13-30, 2011.

[19] G. Abebe and A. Alemu, "Role of improved seeds towards improving livelihood and food security at Ethiopia," International Journal of Research-GRANTHAALAYAH, vol. 5, no. 2, pp. 338-356, 2017.

[20] A. Nezhadahmadi, Z. H. Prodhan, and G. Faruq, "Drought tolerance in wheat," Science World Journal, vol. 1-12, 2013.

[21] M. Lamaoui, M. Jemo, R. Datla, and F. Bekkaoui, "Heat and drought stresses in crops and approaches for their mitigation," Frontiers in Chemistry, vol. 6, p. 26, 2018.

[22] M. Ashraf and M. R. Foolad, "Roles of glycine betaine and proline in improving plant abiotic stress resistance," Environmental and Experimental Botany, vol. 59, no. 2, pp. 206216, 2007.

[23] A. Marmar, S. Baenziger, and I. Dweikat, "Preliminary screening for water stress tolerance and genetic diversity in wheat (Triticum aestivum L.) cultivars from Sudan," Journal of Genetic Engineering and Biotechnology, vol. 11, no. 2, pp. 87-94, 2013.

[24] N. S. Kacem, F. Delporte, Y. Muhovski, A. Djekoun, and B. Watillon, "In vitro screening of durum wheat against waterstress mediated through polyethylene glycol," Journal of Genetic Engineering and Biotechnology, vol. 15, no. 1, pp. 239-247, 2017.

[25] T. T. Kozlowski and S. G. Pallardy, "Acclimation and adaptive responses of woody plants to environmental stresses," The Botanical Review, vol. 68, no. 2, pp. 270-334, 2002.

[26] S. Zhang, L. Shan, and X. Deng, "Change of water use efficiency and its relation with root sys-tem growth in wheat evolution," Chinese Science Bulletin, vol. 47, no. 22, pp. 1879-1883, 2002.

[27] B. Duan, Y. Yang, Y. Lu, H. Korpelainen, F. Berninger, and C. Li, "Interactions between water deficit, $\mathrm{ABA}$, and 
provenances in Picea asperata," Journal of Experimental Botany, vol. 58, no. 11, pp. 3025-3036, 2007.

[28] R. Nazar, S. Umar, N. A. Khan, and O. Sareer, "Salicylic acid supplementation improves photosynthesis and growth in mustard through changes in proline accumulation and ethylene formation under drought stress," South African Journal of Botany, vol. 98, pp. 84-94, 2015.

[29] R. Manuchehri and H. Salehi, "Physiological and biochemical changes of common bermudagrass (Cynodon dactylon [L.] Pers.) under combined salinity and deficit irrigation stresses," South African Journal of Botany, vol. 92, pp. 83-88, 2014.

[30] IUSS Working Group WRB, "International soil classification system for naming soils and creating legends for soil maps," FAO, Rome, Italy, 2014.

[31] A. Khakwani, M. Dennett, and M. Munir, "Drought tolerance screening of wheat varieties by inducing water stress conditions," Songklanakarin Journal of Science and Technology, vol. 33, no. 2, pp. 135-142, 2011.

[32] S. Martin, "CROPWAT: A Computer Program for Irrigation Planning and Management," 1996.

[33] R. G. Allen, L. S. Pereira, D. Raes, and M. Smith, "Crop Evapotranspiration Guidelines for Computing Crop Water requirements," 1998.

[34] M. Schonfeld, R. Johnson, B. Carver, and D. Mornhinweg, "Water relations in winter wheat as drought resistance indicators," Crop Science, vol. 28, pp. 536-541, 1988.

[35] L. S. Bates, R. P. Waldren, and I. D. Teare, "Rapid determination of free proline for water-stress studies," Plant and Soil, vol. 39, no. 1, pp. 205-207, 1973.

[36] M. Dubois, K. A. Gilles, J. K. Hamilton, P. A. Rebers, and F. Smith, "Colorimetric method for determination of sugars and related substances," Analytical Chemistry, vol. 28, no. 3, pp. 350-356, 1956.

[37] S. Tiwari, C. Lata, P. S. Chauhan, and C. S. Nautiyal, "Pseudomonas putida attunes morphophysiological, biochemical and molecular responses in Cicer arietinum $L$. during drought stress and recovery," Plant Physiology and Biochemistry, vol. 99, pp. 108-117, 2016.

[38] P. Manivannan, C. A. Jaleel, R. Somasundaram, and R. Panneerselvam, "Osmoregulation and antioxidant metabolism in drought-stressed Helianthus annuus under triadimefon drenching," Comptes Rendus Biologies, vol. 331, no. 6, pp. 418-425, 2008.

[39] T. Mushtaq, M. Hussain, H. Bukhsh, J. Iqbal, and T. Khaliq, "Evaluation of two wheat genotypes performance under drought conditions at different growth stages," Journal of Crop and Environment, vol. 2, no. 2, pp. 20-27, 2011.

[40] N. K. Gupta, S. Gupta, and A. Kumar, "Effect of water stress on physiological attributes and their relationship with growth and yield of wheat cultivars at different stages," Journal of Agronomy and Crop Science, vol. 186, no. 1, pp. 55-62, 2001.

[41] T. Y. Bayoumi, M. H. Eid, and E. M. Metwali, "Application of physiological and biochemical indices as a screening technique for drought tolerance in wheat genotypes," Africa Journal of Biotechnology, vol. 7, pp. 2341-2352, 2008.

[42] M. A. Shahzad, S. T. Sahi, M. M. Khan, and M. Ahmad, "Effect of sowing dates and seed treatment on grain yield and quality of wheat," Pakistan Journal of Agricultural Science, vol. 44, pp. 581-583, 2007.

[43] A. Jemal, T. Tamado, and E. Firdissa, "Response of bread wheat (Triticum aestivum L.) varieties to seeding rates at Kulumsa, southeastern Ethiopia," Asian Journal of Plant Science, vol. 14, pp. 50-58, 2015.
[44] S. A. Memon, I. A. Sheikh, M. A. Talpur, and M. A. Mangrio, "Impact of deficit irrigation strategies on winter wheat in semi-arid climate of sindh," Agricultural Water Management, vol. 243, 2021.

[45] N. Rahim, S. Abas, K. Hamid, M. Amir, and N. Kamvan, "Effect of plant density on grain yield, yield components and associated traits of three durum wheat cultivar in western Iran," Journal of Agricultural and Crop Science, vol. 4, no. 2, pp. 79-85, 2012.

[46] M. Bajjii, J. M. Kinet, and S. Lutts, "The use of the electrolyte leakage method for assessing cell membrane stability as a water stress tolerance test in durum wheat," Plant Growth Regulation, vol. 36, no. 1, pp. 61-70, 2001.

[47] S. Abdul Raziq, U. Sana, K. Shahbaz et al., "Influence of seed size on germinability and grain yield of wheat (Triticum aestivum L.) varieties," Journal of Natural Science and Research, vol. 4, no. 23, pp. 124-142, 2014.

[48] P. Korir, J. Nyabundi, and P. Kimurto, "Genotypic response of common bean (Phaseolus vulgaris L.) to moisture stress condition in Kenya," Asian Journal of Plant Science, vol. 5, no. 1, pp. 24-32, 2006.

[49] J. A. Strauss and G. A. Agenbag, "The use of physiological parameters to identify drought tolerance in spring wheat cultivars," South African Journal of Plant and Soil, vol. 17, no. 1, pp. 20-29, 2000.

[50] H. Lessani and M. Mojtahedi, Introduction to Plant Physiology (Translation), Tehran University press, Iran, 6th edition, 2002.

[51] P. A. Sikuku, J. C. Onyango, and D. M. Musyimi, "Chlorophyll fluorescence, protein and chlorophyll content of three nerica rainfed rice varieties under varying irrigation regimes," Journal of Agricultural and Biological Science, vol. 5, pp. 1925, 2010.

[52] C. H. Foyer, M. Lelandais, and K. J. Kunert, "Photooxidative stress in plants," Physiologia Plantarum, vol. 92, no. 4, pp. 696-717, 1994.

[53] M. R. Schlemmer, D. D. Francis, J. F. Shanahan, and J. S. Schepers, "Remotely measuring chlorophyll content in corn leaves with differing nitrogen levels and relative water content," Agronomy Journal, vol. 97, no. 1, pp. 106-112, 2005.

[54] J. L. Araus, T. Amaro, J. Voltas, H. Nakkoul, and M. M. Nachit, "Chlorophyll fluorescence as a selection criterion for grain yield in durum wheat under Mediterranean conditions," Field Crops Research, vol. 55, no. 3, pp. 209-223, 1998.

[55] G. D. Farquhar, S. C. Wong, J. R. Evans, and K. T. Hubick, "Photosynthesis and gas exchange," in Plants under Stress: Biochemistry, Physiology, and Ecology and Their Application to Plant Improvement, H. G. Jones, T. J. Flowers, and M. B. Jones, Eds., pp. 47-69, Cambridge University Press, Cambridge, UK, 1989.

[56] M. Almeselmani, F. Abdullah, F. Hareri et al., "Effect of drought on different physiological characters and yield component in different Syrian durum wheat varieties," Journal of Agricultural Science, vol. 3, pp. 127-133, 2011.

[57] A. Maggio, S. Miyazaki, P. Veronese et al., "Does proline accumulation play an active role in stress-induced growth reduction?," The Plant Journal, vol. 31, no. 6, pp. 699-712, 2002.

[58] Q.-S. Wu and R.-X. Xia, "Arbuscular mycorrhizal fungi influence growth, osmotic adjustment and photosynthesis of citrus under well-watered and water stress conditions," Journal of Plant Physiology, vol. 163, no. 4, pp. 417-425, 2006.

[59] J. Lipiec, C. Doussan, A. Nosalewicz, and K. Kondracka, "Effect of drought and heat stresses on plant growth and yield: 
a review," International Agrophysics, vol. 27, no. 4, pp. 463-477, 2013.

[60] N. Arabzadeh, "The effect of drought stress on soluble carbohydrates (sugars) in two species of Haloxylon persicum and Haloxylon aphyllum," Asian Journal of Plant Science, vol. 11, no. 1, pp. 44-51, 2012.

[61] J. Hou, X. Huang, W. Sun et al., "Accumulation of watersoluble carbohydrates and gene expression in wheat stems correlates with drought resistance," Journal of Plant Physiology, vol. 231, pp. 182-191, 2018.

[62] A. Hassanein, "Effect of relatively high concentrations of mannitol and sodium chloride on regeneration and gene expression of stress tolerant (Alhagi graecrum) and stress sensitive (Lycopersicon esculentum L.) plant species," Journal of Plant Physiology, vol. 30, pp. 19-36, 2004.

[63] E. D. Shulze, E. Beck, and K. Muller-Hohenstain, Plant Ecology, Springer, Berlin, Heidelberg, 2005.

[64] L. Taiz and E. Zeiger, Plant Physiology, Sinauer Associates, Sunderland, MA, USA, 4th edition, 2006.

[65] A. Mafakheri, A. Siosemardeh, B. Bahramnejad, P. Struik, and Y. Sohrabi, "Effect of drought stress on yield, proline and chlorophyll contents in three chickpea cultivars," Australian Journal of Crop Science, vol. 4, pp. 580-585, 2010.

[66] N. Philipp, H. Weichert, U. Bohra, W. Weschke, A. W. Schulthess, and H. Weber, "Grain number and grain yield distribution along the spike remain stable despite breeding for high yield in winter wheat," PLoS ONE, vol. 13, no. 10, 2018.

[67] Y. Alaei, "The Effect of amino acids on leaf chlorophyll content in bread wheat genotypes under drought stress conditions," Middle-East Journal of Science Report, vol. 10, pp. 99-101, 2011.

[68] M. Abid, Z. Tian, S. T. Ata-Ul-Karim et al., "Nitrogen nutrition improves the potential of wheat (Triticum aestivum L.) to alleviate the effects of drought stress during vegetative growth periods," Frontiers in Plant Science, vol. 7, p. 981, 2016.

[69] J. D. Butler, P. F. Byrne, V. Mohammadi, P. L. Chapman, and S. D. Haley, "Agronomic performance of Rht alleles in a spring wheat population across a range of moisture levels," Crop Science, vol. 45, no. 3, pp. 939-947, 2005. 